\title{
Avian Analysis of LCTA Core Plot Data: West Point Military Academy
}

by

Eric R. Schreiber and Alison Hill

The Land Condition Trend Analysis (LCTA) program is the Army's standard for land inventory and monitoring, using standard methods for natural resources data collection, analyses, and reporting designed to meet multiple goals and objectives. This report presents the results of a study done for West Point in conjunction with the Army Environmental Center's (AEC) Conservation Assistance Program (CAP).
Seven years of bird data were analyzed for 34 LCTA core wildlife plots during 1991 through 1997 . The information and techniques presented in this report are intended to provide land managers the ability to more effectively use the LCTA bird data being collected on their installation. 


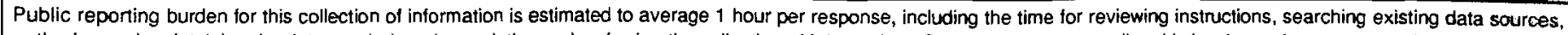

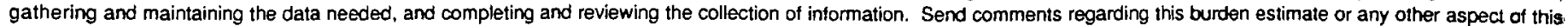

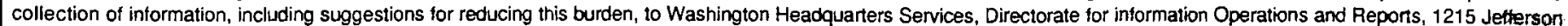
Davis Highway, Suite 1204, Arlington, VA 22202-4302, and to the Otfice of Management and Budget, Papenwork Reduction Project (0704-018B), Washington, DC 20503.

\begin{tabular}{|l|l|l|}
\hline 1. AGENCY USE ONLY (Leave Blank) & $\begin{array}{c}\text { 2. REPORT DATE } \\
\text { August } 1998\end{array}$ & $\begin{array}{l}\text { 3. REPORT TYPE AND DATES COVERED } \\
\text { Final }\end{array}$
\end{tabular}

\begin{tabular}{|l|l|} 
4. TITLE AND SUBTITLE & 5. FUNDING NUMBERS
\end{tabular}

Avian Analysis of LCTA Core Plot Data: West Point Military Academy

Reimbursable Order No.

CAP 060497 and 0697-003

6. AUTHOR(S)

Eric R. Schreiber and Alison Hill

7. PERFORMING ORGANIZATION NAME(S) AND ADDRESS(ES)

U.S. Army Construction Engineering Research Laboratories (USACERL)

P.O. Box 9005

Champaign, IL 61826-9005

8. PERFORMING ORGANIZATION

REPORT NUMBER

SR $98 / 102$

9. SPONSORING / MONITORING AGENCY NAME(S) AND ADDRESS(ES)

Commander, West Point Military Academy

ATTN: DHPW

Natural Resources Branch

West Point, NY 10996

11. SUPPLEMENTARY NOTES

Copies are available from the National Technical Information Service, 5285 Port Royal Road, Springfield, VA 22161.

12a. DISTRIBUTION / AVAILABILITY STATEMENT

12b. DISTRIBUTION CODE

Approved for public release; distribution is unlimited.

13. ABSTRACT (Maximum 200 words)

The Land Condition Trend Analysis (LCTA) program is the Army's standard for land inventory and monitoring, using standard methods for natural resources data collection, analyses, and reporting designed to meet multiple goals and objectives. This report presents the results of a study done for West Point in conjunction with the Army Environmental Center's (AEC) Conservation Assistance Program (CAP).

Seven years of bird data were analyzed for 34 LCTA core wildlife plots during 1991 through 1997 . The information and techniques presented in this report are intended to provide land managers the ability to more effectively use the LCTA bird data being collected on their installation.

\begin{tabular}{|c|c|c|c|}
\hline \multirow{2}{*}{$\begin{array}{l}\text { 14. SUBJECT TERMS } \\
\text { West Point Military Academy } \\
\text { Birds } \\
\text { LCTA }\end{array}$} & \multirow{2}{*}{\multicolumn{2}{|c|}{$\begin{array}{l}\text { Land Management } \\
\text { Ecological Surveys }\end{array}$}} & $\begin{array}{l}\text { 15. NUMBER OF PAGES } \\
234\end{array}$ \\
\hline & & & 16. PRICE CODE \\
\hline $\begin{array}{l}\text { 17. SECURITY CLASSIFICATION } \\
\text { OF REPORT } \\
\text { Unclassified }\end{array}$ & $\begin{array}{l}\text { 18. SECURITY CLASSIFICATION } \\
\text { OF THIS PAGE } \\
\text { Unclassified }\end{array}$ & $\begin{array}{l}\text { 19. SECURITY CLASSIFICATION } \\
\text { OF ABSTRACT } \\
\text { Unclassified }\end{array}$ & $\begin{array}{l}\text { 20. LIMITATION OF } \\
\text { ABSTRACT } \\
\text { SAR }\end{array}$ \\
\hline
\end{tabular}




\section{Foreword}

This study was conducted for The U. S. Military Academy (USMA), West Point Environmental Office under the Conservation Assistance Program (CAP), tracking numbers 060497 and 0697-003. The technical monitor was Ms. Catherine Coleman, DHPW.

The work was performed by the Natural Resource Assessment and Management Division (LL-N) of the Land Management Laboratory (LL), U.S. Army Construction Engineering Research Laboratories (USACERL). The authors would like to acknow-ledge Ms. Catherine Coleman, USMA Integrated Training Area Management (ITAM) program manager, for providing raw data, maps, and reviewing drafts of the manuscript; Joe Deschenes, USMA Forester, Chief, Natural Resources Branch; Tom Miller, research specialist, who collected all the bird data on West Point from 1991 through 1997. The USACERL principal investigator was Dr. Alison Hill. Dr. William D. Severinghaus is the responsible Technical Director. The USACERL technical editor was Gloria J. Wienke, Technical Resources.

COL James A. Walter is Commander and Dr. Michael J. O'Connor is Director of USACERL.

This revised report, dated August 1998, supersedes the previous edition, which is no longer approved for public release. 


\section{Contents}

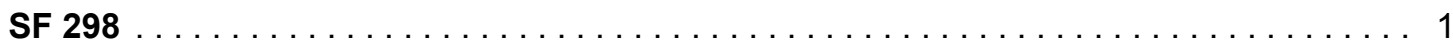

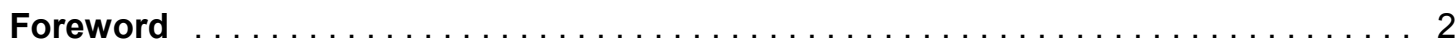

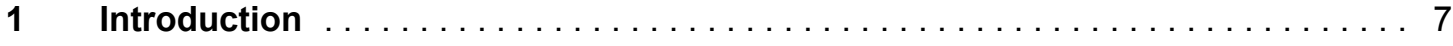

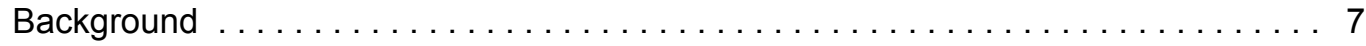

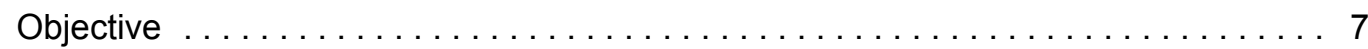

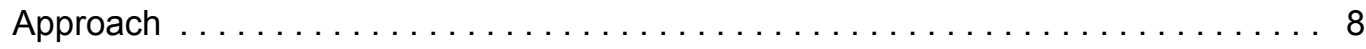

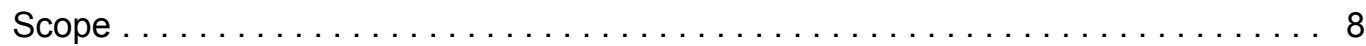

Mode of Technology Transfer $\ldots \ldots \ldots \ldots \ldots \ldots \ldots \ldots \ldots \ldots \ldots \ldots$

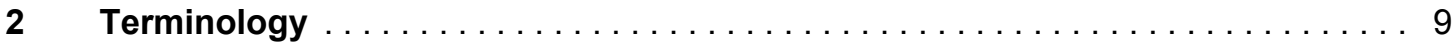

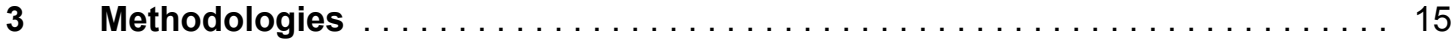

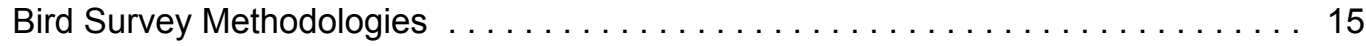

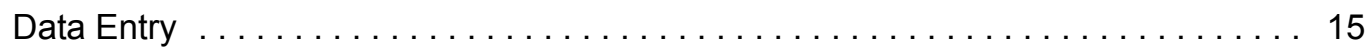

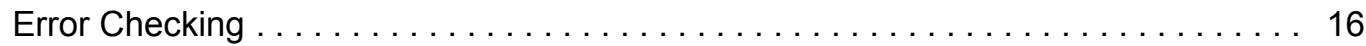

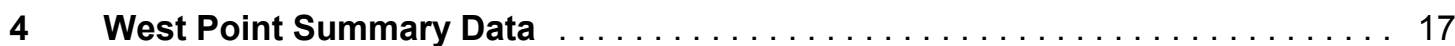

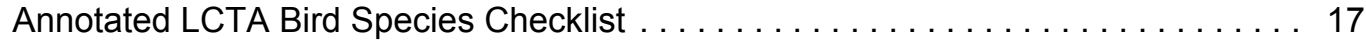

LCTA Plots Associated With Each Bird Species . . . . . . . . . . . . . . . . . . 17

Bird Species Associated With Each LCTA Plot . . . . . . . . . . . . . . . . . . . . . 17

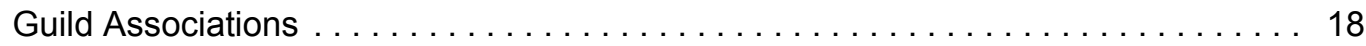

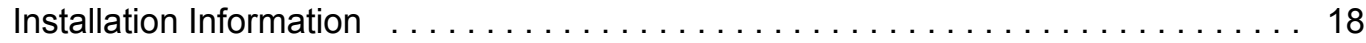

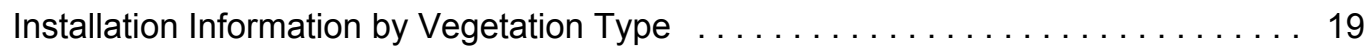

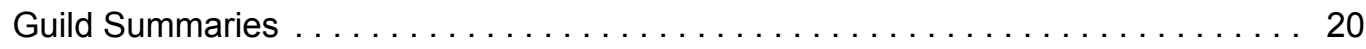

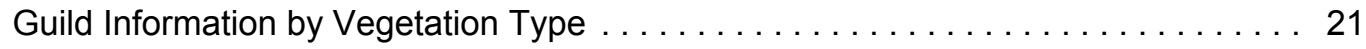

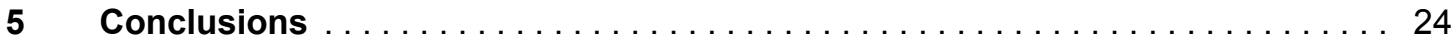

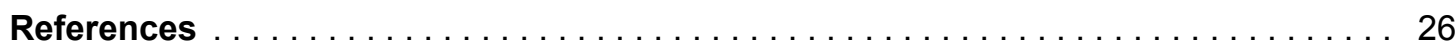

Appendix A: West Point Bird Species Checklist

Table A. Annotated LCTA bird species checklist for West Point with total number of birds per year $\ldots \ldots \ldots \ldots \ldots \ldots \ldots \ldots \ldots \ldots \ldots \ldots \ldots \ldots \ldots \ldots \ldots$

Appendix B: Plot Numbers for Each West Point Bird Species

Table B. LCTA plot numbers associated with each West Point bird species . . . . . B-1 


\section{Appendix C: West Point Bird Species On Each LCTA Plot}

Table C. Bird species checklist for West Point by plot $\ldots \ldots \ldots \ldots \ldots \ldots \ldots$ C-1

\section{Appendix D: Guild Associations for Each West Point Bird Species}

Table D. Guild association for each West Point bird species $\ldots \ldots \ldots \ldots \ldots$ D-1

\section{Appendix E: West Point Summary Information}

Table E1. General information for West Point bird data (1991-1997) . . . . . . . E1-1

Table E2. Installation information for West Point by year $\ldots \ldots \ldots \ldots \ldots \ldots$ E1-1

Table E3. Installation information for West Point by period $\ldots \ldots \ldots \ldots \ldots \ldots$ E1-1

Table E4. Installation information for West Point by transect . . . . . . . . . . E E4-1

Table E5. Installation information for West Point by mated status . . . . . . . . . E E-1

\section{Appendix F: West Point Summary Information by Vegetation Type}

Table F1. Vegetation types for West Point LCTA bird plots that were used in the analyses $\ldots \ldots \ldots \ldots \ldots \ldots \ldots \ldots \ldots \ldots \ldots \ldots \ldots \ldots \ldots \ldots \ldots \ldots .1$

Table F2. Installation summary for West Point by vegetation type $\ldots \ldots \ldots \ldots$ F2-1

Table F3. Vegetation types for West Point by year $\ldots \ldots \ldots \ldots \ldots \ldots \ldots \ldots$ F3-1

Table F4. Vegetation types for West Point by period . . . . . . . . . . . . F F-1

Table F5. Vegetation types for West Point by transect $\ldots \ldots \ldots \ldots \ldots \ldots \ldots$ F5-1

Table F6. Vegetation types for West Point by mated status $\ldots \ldots \ldots \ldots \ldots$ F6-1

Table F7. Vegetation types for West Point by species $\ldots \ldots \ldots \ldots \ldots \ldots \ldots$ F7-1

\section{Appendix G: West Point Guild Summary Information}

Table G1. Guild summaries for West Point by neotropical status ......... G1-1

Table G2. Guild summaries for West Point by nest location . . . . . . . . G2-1

Table G3. Guild summaries for West Point by nest type . . . . . . . . . . . . G3-1

Table G4. Guild summaries for West Point by food type . . . . . . . . . . . . G4-1

Table G5. Guild summaries for West Point by feeding substrate . . . . . . . G5-1

Table G6. Guild summaries for West Point by foraging technique . . . . . . . . G6-1

Table G7. Guild summaries for West Point by habitat type . . . . . . . . . . G7-1

\section{Appendix H: West Point Guild Summary Information by Vegetation Type}

Table H1. Vegetation types for West Point by neotropical status $\ldots \ldots \ldots \ldots \mathrm{H} 1-1$

Table H2. Vegetation types for West Point by nest location . . . . . . . . H2-1

Table H3. Total number of birds within each vegetation type by nest location . . . H3-1

Table H4. Vegetation types for West Point by nest type . . . . . . . . . . . H4-1

Table H5. Total number of birds within each vegetation type by nest type . . . . H5-1

Table H6. Vegetation types for West Point by food type . . . . . . . . . . H6-1

Table H7. Total number of birds within each vegetation type by food type $\ldots \ldots$ H7-1

Table H8. Vegetation types for West Point by feeding substrate . . . . . . . . H8-1

Table H9. Total number of birds within each vegetation type by feeding substrate H9-1

Table H10. Vegetation types for West Point by foraging technique . . . . . . H H

Table H11. Total number of birds within each vegetation type by foraging

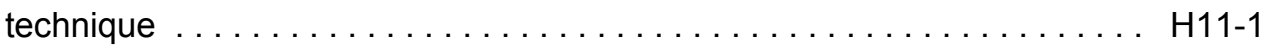

Table H12. Vegetation types for West Point by habitat type $\ldots \ldots \ldots \ldots \ldots$ H12-1 
Table H13. Total number of birds within each vegetation type by habitat type . . H13-1

Distribution 


\section{Introduction}

\section{Background}

The U.S. Army is currently responsible for managing 5 million hectares (12.4 million acres) on approximately 120 military installations throughout the United States. More than 50 military installations and training areas in the United States and Germany have implemented the Land Condition Trend Analysis (LCTA) program (Tazik et al. 1992).

The U.S. Army Construction Engineering Research Laboratories (USACERL) developed LCTA as a means to inventory and monitor natural resources on military installations. The LCTA program uses standardized methods of nature resource data collection, analysis, and reporting designed to meet the need for natural resources management and land stewardship (Tazik et al. 1992).

The Environmental Office at West Point Military Academy began collecting LCTA bird survey data in 1991. West Point is unique in that one individual, Mr. Tom Miller, collected all 7 years (1991 through 1997) of the LCTA bird data. In June 1997, Ms. Catherine Coleman of the Environmental Office at West Point contacted Mr. Steve Getlein, the Conservation Assistance Program (CAP) program manager, at the Army Environmental Center, and submitted a CAP request for assistance with analyzing their LCTA bird data. West Point had interest in obtaining general trend information over time and knowing about the stability of the local bird population, with particular interest in songbirds and raptors.

\section{Objective}

The objective of this research was to produce summary tables of West Point's LCTA core plot bird data. 


\section{Approach}

Once the project was assigned on 25 June 1997, the USACERL and West Point investigators held a conference call to discuss the work and come to an agreement on the desired final product: a report containing digital summary tables of the LCTA bird data. The following tasks were completed in response to West Point's CAP request:

(1) Verified and fixed all errors within the 1991 - 1997 bird data.

(2) Entered the revised bird data into Quest for analysis.

(3) Analyzed the 1991 - 1997 bird data for 34 LCTA core plots.

(4) Prepared a Draft report for West Point on the bird data.

(5) Provided West Point specific guild information on local species.

(6) Reran queries to accommodate changes in the New York Natural Heritage (NYNH) Communities map.

(7) Prepared a Final report for West Point.

(8) Sent West Point electronic files of the revised data and output and a hard copy of the final report.

\section{Scope}

This report summarizes West Point's bird data collected by using standard LCTA data collection techniques. It provides summaries of LCTA core plot data from 1991 through 1997.

\section{Mode of Technology Transfer}

West Point can use the compiled summary tables to support land management decisionmaking and to support the required documentation. This documentation includes, but is not limited to annual installation reports, the Integrated Natural Resource Management Plan (INRMP), and National Environmental Policy Act (NEPA) documents. All electronic files of the raw and compiled data will be transferred to West Point.

As an ongoing effort, the information in this report will be used to analyze and compare West Point bird data with the Breeding Bird Survey data. This work can be adapted to other installations and can serve as an example to other installations for analyzing, compiling, and reporting their own data. 


\section{Terminology}

The variables used in the summary tables are defined below.

Ave FO birds - The average number of flyovers for each LCTA plot.

Ave site birds - The average number of birds recorded within the confines of the LCTA plot boundary.

Ave tot birds - The average number of birds recorded for each LCTA plot; includes both flyover and site species.

Distinct species - The term distinct species is synonymous with unique species. A total of 100 distinct onsite species (105 - 5 unknown species) and 17 flyover species were identified on West Point LCTA plots during 1991 through 1997.

FO birds - Flyovers are birds that were observed outside the designated LCTA plot boundary.

FO plots - The number of LCTA plots in which flyover species were recorded as occurring outside the plot boundary or flying overhead. Flyover species were typically not used in analyses since they were not specifically associated with a particular habitat type, but rather are transient.

Occurrence - Occurrence means record. A record refers to each time a species is recorded on an LCTA plot. For example, if a black-capped chickadee occurred on five LCTA plots it would be recorded as five occurrences. There was a total of 8,122 individual species occurrences, including flyovers, on West Point LCTA plots during 1991 through 1997.

Period - Time of day in which the survey was conducted.

AM - morning

$\mathrm{PM}$ - evening 
Plotid - The plot identification number associated with each West Point LCTA wildlife plot. The 34 LCTA core bird plots were sampled annually during 1991 through 1997.

Site birds - The total number of birds identified within the LCTA plot boundary.

Site plots - The total number of LCTA plots on which species were recorded.

Total birds - The total number of birds recorded on West Point LCTA plots; includes both flyovers and site species.

Transect - Portion of the line transect in which species were recorded.

Line Out - Starting at the $0 \mathrm{~m}$ of the transect and walking to the $100 \mathrm{~m}$ end. End Point - The end of the 100-m transect.

Line In - Walking from the end point back to the $0 \mathrm{~m}$ point.

Vertid - LCTA wildlife codes were established in 1991 by researchers from USACERL (Kowalski and Whitworth 1991) and based on the scientific names from the 1987 Checklist of Vertebrates (Banks, McDiarmid, and Gardner 1987). Each code consists of the first two letters of the genus and the first two letters of the specific epithet. If duplicate codes exist, ascending numbers, starting with 1 , follow the four-letter code.

The following variables were used in the tables to describe guild information for the 100 distinct onsite West Point bird species.

Food type - The primary food eaten by West Point birds.

- Aquatic Inverts - Includes aquatic insects, crayfish, shrimp, snails, bivalves, etc.

- Birds - Includes birds and their eggs.

- Carrion - Dead and putrefying flesh.

- Fish - Includes fish, their fry, and eggs.

- Fruit - Includes fruit and berries.

- Greens - May include leafy parts of both aquatic and terrestrial plants, and bulbs.

- Insects - May include insects, spiders, mites, land snails, slugs, worms, millipedes, sowbugs, etc.

- Nectar - The sugar-containing liquid secretion of the nectary of many flowers.

- Seeds - Includes grains, sunflower seeds, conifer seeds, etc. 
- Small Mammals - Any animal of the class Mammalia. Includes shrews, ground squirrels, rabbits, but most often rodents.

General Habitat - General habitat is a category that is often quite difficult to quantify. Many species frequent several habitat types and are not confined to just one. Therefore, habitat classifications within the database should be viewed cautiously.

- Coastal - An area of land near the shore (Pacific and Atlantic Coast).

- Forest - An extensive concentration of trees and related vegetation. Includes sparsely wooded areas, densely wooded areas, and pinon-juniper associations.

- Forest Edge - The transitional area where a forest ends and another distinct habitat begins.

- Freshwater - Includes areas such as lakes, ponds, rivers, and streams.

- Grassland - An area of land on which the natural dominant plant forms are grasses and forbs. Areas with scattered trees and/or snags are included in this community type.

- Riparian - An area located along the bank of a natural watercourse (as a river) or sometimes of a lake or tidewater.

- Shoreline - The strip of land where a body of water and the shore meet.

- Shrubland - An area of land on which the natural dominant plant forms are shrubs (a low, usually several-stemmed woody plant).

- Swamp/Marsh - A wet, spongy land, saturated and sometimes partially or intermittently covered with water. Also includes tracts of soft, wet land, typically characterized by grasses and cattails.

Mated status - The categories used to describe the mated status of West Point bird species.

- Female only

- Flock

- Non-singing male

- Not recorded

- Pair (adult male and female)

- Singing male

- Unknown sex

- Young of the year

Neo status - Neotropical migrant status of West Point species based on the following classification system (Partners in Flight 1991).

A "True" neotropical migrants; breed in North America and winter south of the United States. 
B Generally breed and winter in North America, but some populations winter south of the United States.

R Resident species (i.e., non-neotropical migrant species).

Nest location - The location where West Point bird species nest.

- Bank - Includes river banks, areas of soft soil on steep island slopes, etc., where nest burrows are excavated.

- Cliff - Includes nests situated in natural crevices or on ledges of cliffs typically offering a commanding view of a defensible position, and sometimes chosen when no suitable trees are available.

- Ground - Includes nests placed among the roots, or in niches among the roots of fallen trees, among tules and reeds (in marshes), among grasses, on bare rock, or simply scraped in the dirt or sand.

- Man-made Structure - Includes nests placed among any man-made structure (bridge, barn, etc.).

- Reed - Nest built within and attached to reeds.

- Shrub-Includes nests placed within any multi-stemmed woody plant that does not have a distinct single trunk extending several feet between the ground and the lowest branching point.

- Snag - Includes nests placed in a standing dead tree. Also used for species that use cavities in dead and live trees more/less indiscriminately.

- Woody Lower Canopy - Includes nests placed in the lower canopy of deciduous or coniferous trees.

- Woody Upper Canopy - Includes nests placed in the upper canopy of deciduous or coniferous trees.

Nest type - The type of nest that is constructed by West Point bird species.

- Burrow - Eggs placed in a chamber at the end of a tunnel. Tunnels are either excavated by the bird (most kingfishers, puffins, storm petrels) or usurped from small mammals, especially ground squirrels and prairie dogs.

- Cavity - Eggs placed in a cavity that has been excavated (woodpeckers) or in a natural cavity found in a dead or dying tree. Sometimes a cup or other structure is built within.

- Cup - A sometimes bulky, but always deep depression, with a hemispherical inside and a rim height several times the diameter of the eggs.

- None - No nest is constructed. Eggs typically are layed on ground with nothing to protect them.

- Oven - Oven-shaped (roofed or arched) nest on the ground.

- Parasitic - No nest is constructed. Eggs are deposited in the nest of another species. 
- Pendant - An elongate saclike nest suspended from a branch.

- Platform - A structure in a tree, on a cliff, or providing a dry place above marshy ground or water, usually big enough for the bird to land on, with or without a distinct depression to hold the eggs. Typical of many raptors and wetland birds.

- Saucer - A shallow cup with the height of the rim not more than twice the diameter of the eggs. Also a flattened nest of pliable vegetation as used by some wetland birds.

- Scrape - A simple depression usually with a rim sufficient to prevent eggs from rolling away. The scrape nest of many duck species are almost bowlshaped. Occasionally with lining added.

Substrate - The location where West Point bird species feed.

- Air - Foraging done in the air. Includes foraging techniques such as: Aerial Foraging, Aerial Pursuit, Hawker, Hover \& Pick, Hover Gleaner, and Piracy.

- Bark - Foraging done primarily on the bark of trees. Includes: Bark Gleaner.

- Foliage - Foraging done primarily on foliage. Includes: Foliage Browser and Foliage Gleaner.

- Ground - Foraging done primarily on the ground. Includes: Digging, Ground Gleaner, High Patrol, Hover \& Pounce, Low Patrol, Piracy, Scavenger, and Swooper.

- Water - Foraging done primarily on or in the water. Includes: Ambusher, Dabbler, High Dives, Prober, Skimmer, Surface Dips, and Surface Dives.

Technique - The technique used by West Point bird species to obtain their food.

- Aerial Pursuit - Chasing or catching birds in midair, stooping (dropping on flying birds from above, killing them in midair with a blow from the talons), or snatching them from their perches.

- Ambusher - Hunting by standing motionless on a bank or in the water and spearing fish, frogs, etc.

- Bark Gleaner - Gleaning from tree trunks and branches. Includes excavating and drilling into bark.

- Dabbler - Floating on the surface in shallow water, pivoting headfirst downward while raising hind-quarters above the water to reach submerged plants or animals on or near the substrate.

- Foliage Browser - Browsing tender shoots, twigs, and leaves of trees and shrubs for food. 
- Foliage Gleaner - Gleaning from foliage and occasionally from branches. Take invertebrates and/or fruit from the vegetation, not from the surface of the ground.

- Ground Gleaner - Picking up items from the surface of soil, turf, sand, etc.

- Hawker - Sallies from perch on short flights to capture flying insects.

- High Patrol - Soaring at high altitudes in search of carrion or prey.

- Hover Gleaner - Taking nectar, insects, or berries from plants above the ground while hovering.

- Low Patrol - Seeking prey in a low searching flight.

- Scavenger - Feeding on carrion, refuse, or material left unconsumed by other organisms.

- Surface Dives - Floating and then diving under water using feet and/or wings in search of prey.

- Swooper - Snatching prey from the ground in talons after a gliding descent from perch with wings spread. 


\section{Methodologies}

The bird data used in this analysis was collected from West Point LCTA core plots during the 1991 through 1997 field seasons by Mr. Tom Miller, research specialist. Survey methodologies followed standard LCTA protocols (Tazik et al. 1992).

\section{Bird Survey Methodologies}

Bird inventories are conducted on a subsample of all LCTA core plots, usually about 60, by using a modified point-count technique. Each plot is surveyed once in the morning and once in the evening by slowly walking the $100 \mathrm{~m}$ transect in 6 minutes and recording all birds seen and heard within $100 \mathrm{~m}$ of the plot (Line Out). Upon reaching the end of the transect, the observer stops and records all birds seen and heard for 8 minutes within $100 \mathrm{~m}$ of that spot (End Point). The observer then walks another 6 minutes back to the starting point, again recording all birds seen and heard within $100 \mathrm{~m}$ of the plot (Line In). Species observed outside the plot limits and flyover species are also recorded on the standard LCTA Bird Survey Data Form.

Surveys are typically conducted on relatively calm, rainless days, within a 2 - to 4 -week period that corresponds to the breeding season. Morning surveys are conducted between $1 / 2$ hour before and 4 hours after sunrise; evening surveys are conducted 4 hours before sunset. All birds observed, with common name, LCTA species code, and total number for each species are recorded within each segment of the survey, along with corresponding codes for mated status.

\section{Data Entry}

The 1991 through 1997 bird data was entered into SQLBase format from standard LCTA paper data forms. 


\section{Error Checking}

The paper and electronic data files were checked for a number of common errors, which were corrected in the database. LCTA species codes were developed for all wildlife species, and should be used when collecting any LCTA-related data. However, errors may still arise. The various types of errors that may be encountered include: (1) entering an invalid species code (i.e., the species code does not correspond to a valid species, MYMU vs. HYMU), (2) entering the wrong species code for a particular species (i.e., the species code pertains to an entirely different species, VIOL vs. PIOL), (3) omitting the numerical value at the end of certain species codes (e.g., COVI vs. COVI1), (4) entering an incorrect numerical value for certain species codes (e.g., SPPA1 vs. SPPA2).

Some errors can be fixed easily (e.g., correcting for invalid species codes); however, other errors involve cross-referencing back to the original data sheets and checking the species code against the common name. The species code must not only be correct, but legible, because the person entering the data into the database typically relies solely on the species code. Only when error-checking procedures are done, will the individual cross-reference the code to the common name, and correct for these inconsistencies. These errors must be corrected before doing any analyses, otherwise the results may be flawed. 


\section{West Point Summary Data}

\section{Annotated LCTA Bird Species Checklist}

Appendix A/Table A lists, by common name, the 100 distinct bird species recorded on West Point LCTA core plots during 1991 through 1997. The table includes the scientific name, LCTA code, and the total number of individuals recorded for each year. The Wood Thrush was the most frequently observed species recorded on West Point, with 515 occurrences (7.0\%), followed by the Redeyed Vireo with (6.6\%), Scarlet Tanager (6.1\%), Ovenbird (5.1\%), and Blue Jay (4.9\%). Seventeen distinct bird species were also recorded as flyovers, or those occurring outside the plot boundary.

\section{LCTA Plots Associated With Each Bird Species}

Appendix B/Table B lists all LCTA plots in which a particular species was recorded, and the total number of individuals found on each of those plots during 1991 through 1997. Several species were identified on all core plots. These species include: Norther Flicker, Great-crested Flycatcher, Blue Jay, Eastern Wood Pewee, Scarlet Tanager, Wood Thrush, Red-eyed Vireo, and the Black-andwhite Warbler. Additional species occurring on 33 of the 34 LCTA plots include the Northern Oriole, Ovenbird, and the Cedar Waxwing.

\section{Bird Species Associated With Each LCTA Plot}

Appendix C/Table $\mathrm{C}$ lists all avian species recorded for each of the 34 LCTA wildlife plots, and the total number of individuals for each species within that plot during 1991 through 1997. The number of species recorded on individual plots ranged between 27 species (plot 24) and 44 species (plots 9 and 10), with the mean being 34.9 species per plot. 


\section{Guild Associations}

Appendix D/Table D contains generic guild information for the 100 West Point bird species identified on LCTA core plots, with common name, scientific name, LCTA code, neotropical migrant status, nest location, nest type, food type, food substrate, feeding technique, and general habitat. This information was derived from a comprehensive list containing guild data for all bird species found within the United States (Schreiber and Whitworth, Draft).

\section{Installation Information}

Table E1 in Appendix E lists the general information for West Point bird data during 1991 through 1997. All (100\%) of the LCTA core plots had species recorded within the plot boundary. However, in 1993, 3 Raptor species, 2 Woodpecker species, and 1 Wren species were recorded, but not identified to the species level. In 1994, 1 Raptor species and 1 Flycatcher species were recorded, but not identified to the species level. Also, in 1995, 1 Paridae species was recorded but not identified to the species level. These unknown individuals will slightly overestimate the number of site species recorded during 1993 through 1995, but were included to keep the number of total birds and site birds as accurate as possible. Therefore, the number of site species recorded in Table E1 (105 species) actually represents 100 distinct site species (as referenced in Table D).

Table E2 is a similar division of the information presented in Table E1, except it presents the information by year. A total of 100 distinct species $(7,398$ occurrences) were recorded from 1991 through 1997. This includes: 64 species ( 1,558 occurrences) in 1991, 61 species (1,221 occurrences) in 1992, 66 species (69 - 3 unknowns, 864 occurrences) in 1993, 60 species (62 - 2 unknowns, 929 occurrences) in 1994, 65 species (66 - 1 unknown, 967 occurrences) in 1995, 63 species (880 occurrences) in 1996, and 71 species (979 occurrences) in 1997.

Table E3 displays the installation information by year and period (i.e., time of day). The importance of dividing the information by period is to gain insight on which sampling time is best. Plot 3 is excluded from this analysis because it had two different morning times and no evening times. Sampling in the morning clearly provides a much higher yield when looking at the average number of both total and site birds, within all years. However, generally speaking, time of day did not seem overly important when identifying flyover species. 
Table E4 lists the installation information by transect. The data indicate that the three transect segments (Line Out, End Point, and Line In) have no effect on the number of site species being identified. However, Line Out is picking up far more species observations than the other two segments.

Table E5 lists the installation information by mated status for 1992 through 1997. The data collected from 1991 was excluded from analyses since the mated status was not recorded. The singing male was the most frequently recorded category.

\section{Installation Information by Vegetation Type}

Vegetation types (Appendix F, Table F1) were derived from the NYNH Communities map and the LCTA Plot Location map created by West Point personnel.

West Point's 34 LCTA core plots represent 11 vegetative categories. These categories include: Appalachian Oak-Hickory (14 plots), Appalachian Oak-Pine Forest (1 plot), Burn Barren (2 plots), Burn Barren \& Appalachian Oak-Hickory (50/50) (1 plot), Chestnut Oak Forest (7 plots), Hemlock-Northern Hardwood Forest (1 plot), Maple Beech Mesic (2 plots), Oak-Tulip Tree Forest (2 plots), Rich Rocky Woodlands (2 plots), Rocky Summit Grassland (1 plot), and Successional Hardwoods (1 plot) (Table F2). Most vegetative categories had very small sample sizes; subsequent analyses should be viewed with caution.

Table F3 lists the vegetation types for each year, with the total number of birds observed within each category.

Table F4 divides the vegetation types for each year, by period, with the total number of birds associated with each. As mentioned earlier, Plot 3 was excluded from this particular analysis since two morning counts and no evening counts were recorded. With few exceptions, more birds were recorded in morning site bird counts than evening site bird counts.

Table F5 divides the vegetation types by transect, with the total number of birds associated with each. With few exceptions, more bird observations were recorded during the Line Out than during the End Point or Line In. 
Table F6 lists the vegetation types by mated status for each year, with the total number of birds associated with each. Singing males were recorded more frequently than any other mated status, except in 1991, when the mated status was not recorded.

Table F7 separates the West Point vegetation types by species recorded within each category. The number of species identified within each vegetative category is provided below. Small sample sizes should be viewed with caution.

Burn Barren - 48 species (2 plots)

Burn Barren/Oak-Hickory - 50 species (1 plot)

Chestnut Oak - 73 species (7 plots)

Hemlock-Northern Hardwood - 42 species (1 plot)

Maple Beech Mesic - 51 species (2 species)

Oak-Hickory - 88 species (14 plots)

Oak-Pine - 36 species (1 plot)

Oak-Tulip Tree - 53 species (2 plots)

Rich Rocky Woodlands - 51 species (2 plots)

Rocky Summit Grassland - 40 species (1 plot)

Successional Hardwoods - 46 species (1 plot)

\section{Guild Summaries}

Information pertaining to the guild summary tables in Appendix G is based on a report by Schreiber and Whitworth (1998) that documents an LCTA database update that provides selected ecological attributes for 676 bird species occurring within the continental United States.

Table G1 lists West Point bird species by neotropical status: Class A, Class B, and Resident species. Approximately $73 \%$ of the birds identified on West Point core plots were identified as neotropical migrants (Class A and Class B). The breakdown of neotropical migrants and occurrences, by year, are listed below.

\begin{tabular}{|c|c|c|}
\hline Year & \% of migrant species & \% of migrant species occurrences \\
\hline 1991 & 71.9 & 84.4 \\
\hline 1992 & 68.9 & 79.4 \\
\hline 1993 & 69.7 & 76.5 \\
\hline 1994 & 66.7 & 81.4 \\
\hline
\end{tabular}




\begin{tabular}{|l|l|l|}
\hline 1995 & 73.8 & 79.9 \\
\hline 1996 & 73.0 & 77.5 \\
\hline 1997 & 74.6 & 81.5 \\
\hline
\end{tabular}

Table G2 divides West Point's bird species into areas in which nesting occurs. Eight nesting locations were identified. Woody Upper Canopy nesters were the most common (37.2\%), followed by Ground nesters (21.9\%), and Woody Lower Canopy nesters $(20.0 \%)$.

Table G3 divides the bird species into the type of nest that is constructed. Ten nest types were identified. According to the data, the majority of West Point birds make a cup-type nest (63.7\%), followed next by cavity nesters (16.9\%).

Table G4 lists the bird species by the types of foods used. Eight food types were identified. According to the data, nearly $93.0 \%$ of the birds identified on West Point feed on insects, followed by fruit eaters $(2.5 \%)$.

Table G5 lists the bird species by feeding substrate categories. Five distinct feeding substrates were identified from West Point birds. According to the data, most West Point bird species forage on the ground (45.6\%), in the air (24.8\%), and on foliage $(19.8 \%)$.

Table G6 divides the bird species into foraging technique categories. Sixteen foraging techniques have been identified from the birds occurring on West Point. According to the data, the majority of birds were ground gleaners (42.9\%), foliage gleaners (19.4\%), and bark gleaners (9.1\%).

Table G7 lists the species by habitat types. Eight distinct habitat types have been identified from the birds occurring on West Point. According to the data, the majority of birds preferred forested areas (74.2\%), followed nest by forest edge (15.2\%), and shrubland areas (4.4\%).

\section{Guild Information by Vegetation Type}

Table H1 lists the vegetation types for West Point bird species by neotropical migrant status. The overall percentage of neotropical migrants (Class A and Class B) within each vegetation category are listed below.

Burn Barren - 84.8\%

Burn Barren/Oak-Hickory - 83.0\%

Chestnut Oak - 80.5\%

Hemlock-Northern Hardwood- 84.8\% 
Maple Beech Mesic - 81.1\%

Oak-Hickory - 80.0\%

Oak-Pine - 58.1\%

Oak-Tulip Tree - $82.8 \%$

Rich Rocky Woodlands - 85.3\%

Rocky Summit Grassland - 83.1\%

Successional Hardwoods- $74.8 \%$

Table H2 lists the West Point bird species by nest location, with the total number of individuals within each vegetation type, by year.

Table H3 summarizes the information presented in Table H2. Looking at the number of individuals within each vegetation category, most birds on West Point nest in Woody Upper Canopy (37.2\%), followed by Ground nesters (21.9\%), Woody Lower Canopy nesters (20.0\%), and Shrub nesters (11.8\%).

Table H4 lists the West Point bird species by nest type, with the total number of individuals within each vegetation type, by year.

Table H5 summarizes the information presented in H4. More than $63 \%$ of the birds on West Point make cup nests, cavity nests (16.9\%), or saucer-type nests $(6.6 \%)$.

Table H6 divides the West Point bird species by food type, with the total number of individuals within each vegetation category, by year.

Table H7 summarizes the information presented in H6. According to the data, approximately $84 \%$ of West Point birds feed on insects.

Table H8 lists the West Point bird species by feeding substrate, with the total number of individuals within each vegetation category, by year.

Table H9 summarizes the information presented in H8. Nearly $46 \%$ of West Point birds forage on the ground, in the air (24.8\%), or on foliage (19.8\%).

Table H10 divides the West Point bird species by foraging technique, with the total number of individuals within each vegetation category, by year.

Table H11 summarizes the information presented in Table H10. Approximately $43 \%$ of West Point birds are ground gleaners, foliage gleaners (19.4\%), or hover gleaners $(14.8 \%)$. 
Table H12 lists the West Point bird species by habitat type, with the total number of individuals within each vegetation category, by year.

Table H13 summarizes the information presented in Table H12. Approximately $74 \%$ of West Point birds rely on forested areas, forest edge (15.2\%), or shrublands $(4.4 \%)$. 


\section{Conclusions}

A total of 100 avian species (7,398 occurrences) were identified on 34 LCTA core plots at the U.S. Military Academy during the summers of 1991 through 1997. The total number of species and occurrences, by year, are as follows: 64 species (1,558 occurrences) in 1991, 61 species (1,221 occurrences) in 1992, 69 species (864 occurrences) in 1993, 62 species (929 occurrences) in 1994, 66 species (967 occurrences) in 1995, 63 species (880 occurrences) in 1996, and 71 species (979 occurrences) in 1997. An additional 17 distinct species were also identified as flyovers, or those occurring outside the plot boundary.

Regarding overall species occurrence, the Wood Thrush was the most frequently observed species recorded on West Point, with 515 occurrences (7.0\%), followed by the Red-eyed Vireo (6.6\%), Scarlet Tanager (6.1\%), Ovenbird (5.1\%), and Blue Jay $(4.9 \%)$.

The number of species recorded on individual plots ranged between 27 species (Plot 24) and 44 species (Plots 9 and 10), with the average being 34.9 species per plot, for all years combined. Species identified on every LCTA core plot include: Norther Flicker, Great-crested Flycatcher, Blue Jay, Eastern Wood Pewee, Scarlet Tanager, Wood Thrush, Red-eyed Vireo, and the Black-and-white Warbler. Species documented from 33 of the 34 LCTA core plots include the Ovenbird, Northern Oriole, and Cedar Waxwing.

Eleven vegetative categories were recognized from LCTA core plots on West Point. These include: Appalachian Oak-Hickory, Appalachian Oak-Pine Forest, Burn Barren, Burn Barren/Appalachian Oak-Hickory, Chestnut Oak Forest, Hemlock-Northern Hardwood Forest, Maple Beech Mesic, Oak-Tulip Tree Forest, Rich Rocky Woodlands, Rocky Summit Grassland, and Successional Hardwoods.

Approximately 73\% of the species identified from West Point core plots are categorized as neotropical migrants (Class A and Class B), while 27\% are considered Resident species. The percentage of neotropical migrants per year ranged between $66.7 \%$ in 1994 to $74.6 \%$ in 1997 . 
Guild summaries by nesting location, nest type, food type, foraging substrate, foraging technique, and habitat type for bird species occurring within the 34 LCTA core plots are as follows. Of the eight nesting locations, most species nested in the Woody Upper Canopy (37.2\%), on the Ground (21.9\%), or in the Woody Lower Canopy (20.0\%). Of the ten nest types, most species made a cuptype nest $(63.7 \%)$ or a cavity nest $(16.9 \%)$. Of the eight food types used, most species fed on insects $(93 \%)$ or fruit $(2.5 \%)$. Of the five feeding substrates, most species fed on the ground (45.6\%), in the air (24.8\%), or on foliage (19.8\%). Of the sixteen foraging techniques, most species were ground gleaners $(42.9 \%)$, foliage gleaners $(19.4 \%)$, or bark gleaners $(9.1 \%)$. Of the eight habitat types, most species preferred forested areas $(74.2 \%)$, forest edge (15.2\%), or shrubland areas (4.4\%). 


\section{References}

Banks, R.C., R.W. McDiarmid, and A.L. Gardner, Checklist of Vertebrates of the United States, the U.S. Territories, and Canada, Resource Publication 166 (U.S. Fish and Wildlife Service, 1987).

Kowalski, D.G., and W.R. Whitworth, LCTA species code database developed by the U.S. Army Construction Engineering Research Laboratories (1991).

Partners in Flight. 1991. Annual Report (Information and Education Working Group and the National Fish and Wildlife Foundation, Washington, DC), vol. 2, no. 1 (1991).

Schreiber, E.R., and W.R. Whitworth, Land Condition Trend Analysis Bird Database: Ecological Guild-based Summaries, Technical Report 98/100 (USACERL, August 1998).

Tazik, D.J., S.D. Warren, V.E. Diersing, R.B. Shaw, R.J. Brozka, C.F. Bagley, and W.R. Whitworth, U.S. Army Land Condition-Trend Analysis (LCTA) Plot Inventory Field Methods, Technical Report N-92/03/ADA247931 (USACERL, February 1992). 


\section{Appendix A: West Point Bird Species Checklist}




\section{Appendix B: Plot Numbers for Each West Point Bird Species}




\section{Appendix C: West Point Bird Species On Each LCTA Plot}




\section{Appendix D: Guild Associations for Each West Point Bird Species}




\section{Appendix E: West Point Summary Information}




\section{Appendix F: West Point Summary Information by Vegetation Type}




\section{Appendix G: West Point Guild Summary Information}




\section{Appendix H: West Point Guild Summary Information by Vegetation Type}

